Jenni Mikkonen ja Johanna Lahikainen (editointi)

\title{
PILVIÄ JA SATEENKAARIA - KESÄ NEW YORKISSA JULKAISUALAN KOULUTUKSESSA
}

Julkaisualan koulutus Columbian yliopistossa New Yorkissa opetti amerikkalaista työkulttuuria ja kustannusmaailmaa. Sen parasta antia olivat henkilökohtainen ohjaus, irtiotto ja unelman saavuttaminen. Haasteensa toivat pitkät päivät ja lähes tauottoman sosiaalisuuden vaatimus.

\section{Pitkä hakuprosessi}

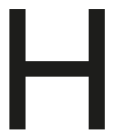
ain Columbian yliopistoon, koska olen aina ollut kiinnostunut uudesta tiedosta ja uusista toimintatavoista. Kun työnkuvani muuttui, kaipasin lisätietoa julkaisemisesta. Osallistuin pari vuotta sitten Suomen tiedekustantajien liiton julkaisemisen peruskurssille ja sitä kautta innostuin lisää.

Hakuprosessi kesti noin viisi kuukautta ja vaati suosituskirjeitä, todistusten käännättämistä, kielitaidon osoittamista, erilaisia motivaatio- ja hakemuskirjeitä sekä ennakkotehtäviä. Koska koulutus oli maksullinen hain ja sain apurahaa Suomen tiedekustantajien liitolta ja tiedetoimittajien liitolta. Ilman tätä tukea, saamiani suosituksia sekä työnantajan kannustusta en olisi voinut hakea ja osallistua kurssille. Olen todella kiitollinen kaikille, jotka auttoivat minua toteuttamaan tämän tavoitteen.

\section{Motivoitunut ryhmä}

Kurssia arvostetaan korkealle Yhdysvalloissa: Se avaa monelle nuorelle hyviä työmahdollisuuksia ja verkostoja erityisesti itärannikolla, johon kustantaminen on keskittynyt.

Ryhmä oli todella motivoitunut ja opintoihin panostettiin: Osa oli hakenut kurssille aikaisempina vuosina ja säästänyt pitkään kurssimaksua varten.

Meitä oli lähes sata opiskelijaa, pääasiassa ympäri Yhdysvaltoja. Suurin osa oli kandeiksi valmistuneita nuoria, jotka halusivat töihin kustannusalalle. Osa oli ollut töissä kirjastoalalla ja olivat kiinnostuneet tiedekustantamisesta, osalla taas ei ollut lainkaan kokemusta julkaisualasta.

Yksi kurssille pääsyn edellytys on, että opiskelijalla on mahdollisuus työllistyä Yhdysvaltojen työmarkkinoille. Koska työpaikan saaminen Yhdysvalloista tai New Yorkista kustannusalalta on tällä hetkellä todella vaikeaa ulko-

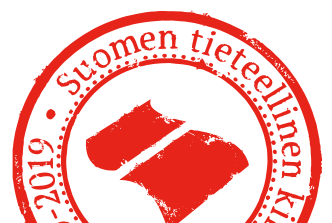


maalaiselle, meitä ulkomaalaisia oli vain muutama.

\section{Uutta oppimassa}

Mieleeni jäi kuvaus "kirjaystävällisistä kaupungeista", joissa ostetaan eniten kirjoja ja joihin kustantajat erityisesti suuntaavat markkinointiaan: niissä on tiivis kirjastoverkosto, hyvä toimeentulotaso ja eniten tohtorintutkintoja.

Erityisen mielenkiintoista oli perehtyminen Michelle Obaman omaelämäkerran (Becoming, 201 8, suom. Minun tarinani, 2018) kulurakenteeseen ja kustannussopimusmalliin sekä siihen mikä merkitys kirjastoilla on julkaisualalle.

\section{Amerikkalaisen kulttuurin pitkät päivät}

Oli ihanaa vaihtelua työelämään Suomessa, kun sai keskittyä kuusi viikkoa pelkästään opintoihin. Elämä oli yksinkertaisempaa, koska esimerkiksi

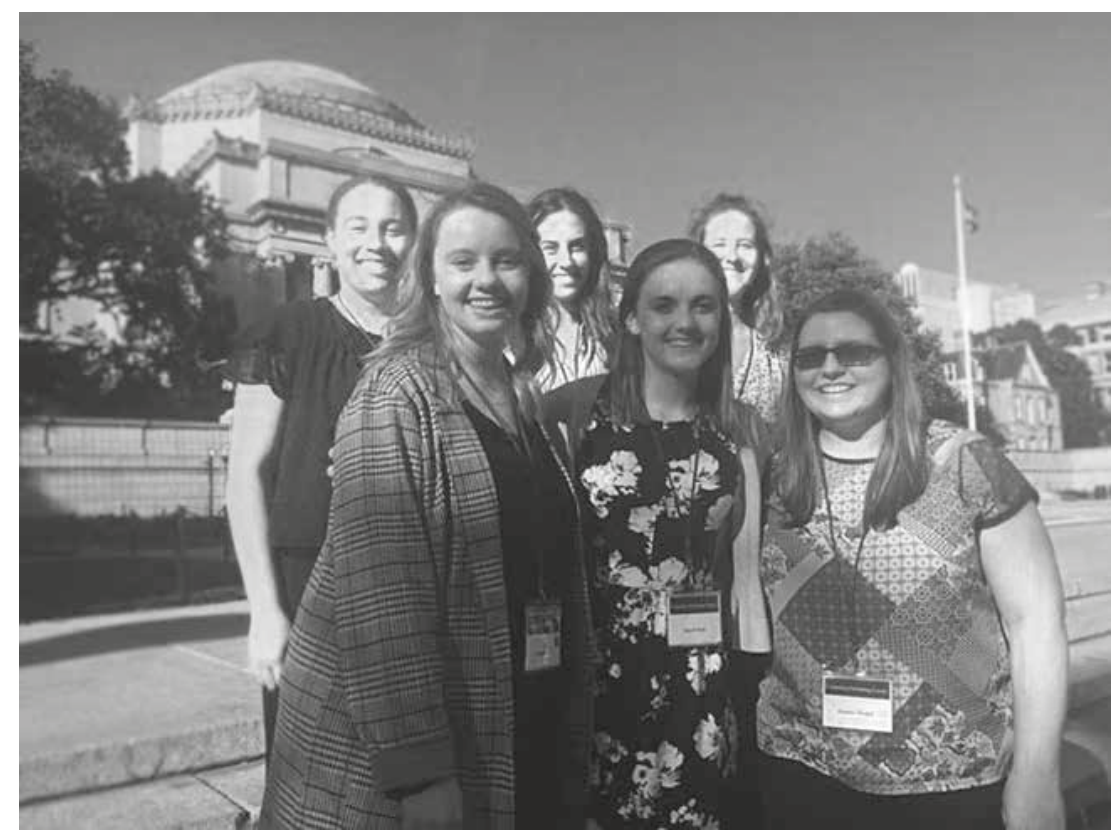

Opiskelu- ja asuinkavereita Columbian yliopistossa: Allison Green (vas.) Caroline Noll, Laura Houck, Mia O’Neill, Jenni Mikkonen ja Jeanna Michel. Kuvan otti Matt Caprioli. 
ruokailu ja majoitus kampusalueella kuuluivat kurssimaksuun.

Luentoja oli joka arkipäivä ja lähes joka lauantai, joten vapaa-aikaa oli vähän. Luennot tai ryhmätyökokoontumiset alkoivat aamupalan jälkeen ja luennot loppuivat iltakahdeksalta, jonka jälkeen tehtiin ryhmätöitä tai henkilökohtaisia tehtäviä joskus yöllä kahteen saakka, joskus pidempäänkin, koska kotitehtävät piti olla palautettuna ennen aamupalaa.

Perinteisten luentojen lisäksi opinnot sisälsivät vierailuja kustantamoihin ja lehtitaloihin, ryhmätöitä, yksilöopetusta ja ohjausta sekä alumnien tapaamisia.

Pidin henkilökohtaisesta ohjauksesta, jota sai ryhmätyöviikoilla joka päivä: kotitehtäviä käytiin läpi ja sai palautetta sekä kannustusta. Kurssi opetti myös uusia opiskelumenetelmiä.

Sisällön lisäksi opin kurinalaisuutta ja tarkkuutta, jota kurssilla vaadittiin. Myös sosiaalisuus, verkostoitumistaidot ja stressinsietokyky kasvoivat. Kurssin loppupuolella, tehdessämme lehtiryhmätyötä, olimme kaikki jo aika väsyneitä, jolloin kurssin johtaja laittoi meille sähköpostia: vaikka olette stressaantuneita ja päivät ovat pitkiä, niin muistakaa olla ystävällisiä toisillenne sekä käyttäytyä hyvin.

Opiskelukaverieni kautta avautui näkökulmia heidän elämäänsä ja arkeensa. Kurssin alkupuolella vanha koulukaverini muutti pysyvästi New Yorkiin, tutkijaksi Columbian yliopis- toon. Hän esitteli minulle kaupunkia ja avasi yliopistokulttuurin lisäksi muuta paikallista kulttuuria. Ilman tätä tulkkia osa kulttuurieroista olisi jäänyt ymmärtämättä.

Pitkien päivien lisäksi jaoin asunnon kolmen kurssikaverin kanssa. Välillä kaipasin omaa tilaa ja rauhaa. Amerikkalaisessa kulttuurissa oli helpompaa lähteä juoksulenkille kuin sanoa, että haluan olla yksin.

\section{Amerikan tuliaisia \\ uosittelen kurssia kaikille, joi- ta kiinnostaa kirja-, lehti- tai monimediainen julkaiseminen} työnä. Erityisesti jos haluaa monipuolisesti tietoa kaupallisesta kustantamisesta. Myös jos kiinnostaa julkaisujen markkinointi, käsikirjoitusten arviointi ja verkostojen luominen Yhdysvaltoihin ja Yhdysvaltojen kustannuskentän tuntemus.

Lisäksi suosittelisin kurssia uran alkuvaiheessa oleville tai uutta urasuuntaa etsiville, koska kurssilla oli paljon luennoitsijoita työelämästä, jotka ohjasivat myös työnhaussa. Kurssilla harjoitellaan itsensä esittelemistä esimerkiksi hissipuheella, työhaastattelutilanteita ryhmän edessä, erilaisten hakemusten ja ansioluetteloiden tekemistä. Kaikesta tästä sai henkilökohtaista palautetta.

Kurssin kautta minulle muistui mieleen ilo siitä, miltä tuntuu, kun on todella hyvin valmistautunut ja hoitanut työnsä tarkasti, kun asioihin on aikaa keskittyä ja paneutua. Tuntui hy- 
vältä, että olin pystynyt toteuttamaan tämän tavoitteen elämässäni. Jäi tunne, että haluaisin oppia vielä lisää.

Käytännön työhöni olen ottanut kurssilta työkaluja esimerkiksi siihen, miten käsikirjoitusehdotuksia arvioidaan ja miten tärkeää viestintäsuunnitelman tekeminen on.

Työelämän ulkopuolella olen alkanut lukea enemmän yhdysvaltalaista kirjallisuutta, seurata enemmän Yhdysvaltojen politiikkaa ja Oprah Winfreyä, joista kiinnostuin opintojen aikana. Jos kirja pääsee Oprahin suosituslistalle, sen kaupallinen menestys on taattu: se voi myydä jopa miljoonia kappaleita.

\section{Pilviä ja sateenkaaria}

Toivon, että voin itsekin auttaa muita saavuttamaan tavoitteitaan tai ainakin kannustamaan oppimaan uutta ja lähtemään rohkeasti ulkomaille kouluttautumaan. Palaan usein näihin Maya Angeloun (I928-20I4) sanoihin, kun jännitän ja mietin, että pystynkö: https://youtu.be/onyxFletwH4

Maya Angeloun mukaan elämässä on paljon pilviä, mutta myös sateenkaaria. Jokaiseen uhkaavaan pilveen elämässä liittyy myös sateenkaari eli henkilö, joka tukee ja on ystävällinen. Ennen esiintymistä Angelou kokosi mielessään mukaansa kaikki ne henkilöt elämänsä varrelta, jotka olivat olleet hänelle ystävällisiä ja kannustavia. Ja siten uskalsi astua lavalle, edetä aina eteenpäin. Tavoitella unelmiaan.

\section{Tietoa kirjoittajista}

Jenni MikKonen

Asiantuntija, tutkimuspalvelut

Taideyliopisto

e-mail: jenni.mikkonen@uniarts.fi

JohanNa LAHIKainen

Signumin päätoimittaja

johanna.lahikainen@helsinki.fi

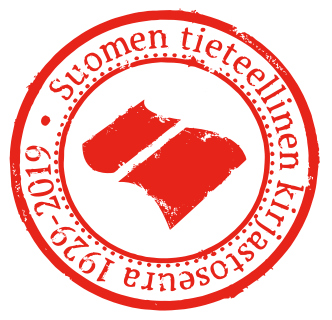

